\title{
The Impact of Environmental and Social Costs Disclosure on Financial Performance Mediating by Earning Management
}

\author{
Khalis Hasan Yousif Al-Naser, University of Mosul, Iraq \\ Hosam Alden Riyadh, Universitas Muhammadiyah Yogyakarta, Indonesia \\ Faeq Malallah Mahmood Albalaki, Bayan University, Iraq
}

\begin{abstract}
This research empirically investigated the effect of environmental cost disclosure (ECD) and social cost disclosure (SCD) on financial performance (FP) mediated by earning management (EM). To achieve this purpose, a quantitative research method was employed using secondary data sources including reports of corporate social responsibility (CSR) and annual reports. Then, the data were examined using smart partial least squares (PLS). The research sample was represented by international energy corporations during the period $(2016,2017$, and 2018). The study results revealed that the environmental and social costs disclosure significantly affected financial performance. This was in agreement with theories of instrumental stakeholders, legitimacy, and agency. This means that more cost on environmental and social information disclosure can generate greater opportunities for corporations.
\end{abstract}

\section{KEYWORDS}

Earning Management, Environmental Cost Accounting, Financial Performance, Social Cost Disclosure

\section{INTRODUCTION}

The phenomenon of environmental and social accounting emerged with the societies' need for social accounting reports similar to those of capital markets. This has required financial data provided by financial accounting frameworks. Likewise, users of social accounting data need information enabling them to judge if the organization is being socially and financially responsible or not. Regardless of social accounting, green accounting and reporting is a new phenomenon and relatively suffered at lack of any mandatory codes or regulation towards the mandatory disclosure. Hence, the organizations are voluntarily engaged in reporting several social responsibility activities in their annual financial reports. Globally, it appears that organizations have progressed in substantial issues further than those found in literature (Eljayash, James \& Kong, 2012; Raey, 2006).

Here, the problem arises when the organization does not invest heavily in environmental reporting due to the poor understanding of environmental issues or increasing the costs of incurred environmental disclosure. According to Ageda (2015), only few investigations have been done in the area of environmental accounting like reporting and its effect on the association's financial performance. Consequently, most associations are starting to spend much of their income on social activities, leading them to vague vision towards environmental accounting. 
There is a long-running discussion on the effect of green or environmental accounting on firms, particularly in corporate financial performance. This discussion illustrates numerous parallels with investigations of corporate social responsibility. The conventional financial argument showed the advantages of natural accounting for firms that will collect a limited extent to the organizations themselves. Therefore, firms have a motivating force to under embrace the environmental accounting disclosures. On the other hand, the government's intervention effort to implement or enforce environmental standards will bring about an exchange off between advantages to society (improvements for environmental measures) and expenses to the firm (lower benefits).

The conflicts started when some authors like Porter (1991); Porter and Van der (1995) argued that progressively stringent guidelines might predominantly provide a long-run increase to firm benefit and profitability. This is done by driving firms to concentrate on decreasing extra generation costs and expanding consumer or purchasers satisfaction and sales. In this context, the effect of empirical connection between environmental and social costs on financial performance is significantly explicit. Thus, exploring a positive relation between the two factors could offer help for the enormous contention. Although observational examinations on both aspects revealed differentiating results, firm heterogeneity or deem powerful impacts on the environmental accounting financial relationship were less investigated in the existing literature. As a result, this study aims at examining the effect of environmental and social costs disclosure on financial performance.

Hence, Epstein and Buhovac (2014) believed that nowadays, enterprises become increasingly oversensitive to environmental issues and partner's concerns and are endeavouring to convert into better corporate residents. Regardless of whether the inspiration is a worry for the society and environment, government guidelines, partner pressures or monetary benefit, the outcome is that managers must unveil huge improvements for a more adequately deal with their environmental effects. The association between environmental and social costs on firm performance in current debate remains inconclusive, offering further explorations for researchers, especially in the context of energy corporations.

Besides, by developing and using environmental accounting, entities may have benefited from several advantages like strict control of environmental expenditure, leading to gaining more customers' trust. Therefore, higher incomes in the long-term sustainability and the environmental information disclosure in annual reports are highly utilized by big firms because of their effectiveness to report, in addition to being the main references of information for outside and inside shareholders such as customers, investors, creditors, employees, government and others.

According to Yousuff, Lehman and Mohd Nasir (2006), more environmental information disclosure can create more room for an organization to improve its reputation. Most organizations present environmental data on their aims, activities and needs. The extent of environmental information disclosure in such reports fluctuates from one organization to another and from one nation to another. The literature revealed that comprehensive and sufficient data recorded by organizations in creating nations fall behind those in created ones. Hence, government administrative powers are less viable in driving the implementation of existing accounting regulations and standards (Ali, Ahmed, and Henry, 2004).

Moreover, societal concern is generally recognized as a significant corporate responsibility to communication between organization and society by social obligation and sustainability. Gray, Bebbington and Walters (1993) claimed that CSED corporate social and environmental disclosure may be considered an authentic and social commitment stipulated by the organization. In any case, because of imperfect transparency and accountability in the real and actual world of finance and economy, managers aim at adopting optional activities over detailed salary to maximize their very own advantage. Healy and Wahlen (1999: 366) stated that earning management (EM) is present when managers or agents either "mislead or misguide some stakeholders about the real firm performance or to influence contractual results, which usually depend on reported statements."

Motivated by the lack of an unanimous opinion on the effect of environmental and social costs disclosure on financial performance, Cavaco and Crifo (2014) aimed at discovering a consensus to 
this relationship by leading a board investigation of 300 greatest European listed market organizations. Their outcomes showed that integral human asset and business activities are definitely connected with financial performance. Also, they discovered that business and substitutable environmental behavior has a constructive relationship with financial performance. Therefore, the organization can be socially capable and profitable by effectively utilizing sustainability, driving new business openings, reducing cost and increasing client certainty. In any case, CSR does not lead directly to better financial performance; it is the consequence of the managers' moves that take into account simultaneously organization development and every social gathering.

Bussy and Suprawan (2012) demonstrated that organizations with great partner connections, such as good stakeholder relationships, especially with staff, are essentially increasingly productive in the medium term contrasted with competitors. Responsibility is likewise observed as expenses and punishments by certain financial specialists, which could prompt diminished returns. This perspective represents the reason why environmental and social costs can likewise prompt decreased future financial performance.

Nevertheless, Barnett's (2007) investigated the genuine point of environmental practices, stating that managers developing economic activities could utilize environmental expenses and natural disclosure as optional exercises, planning to exceed their very own advantage and welfare. Their last objective would modify the faith and support of partners by halting their activism and perceptions while improving corporate notoriety. This opens the way to a doubtful atmosphere regarding the effect of environmental cost disclosure on corporate performance by mediating earnings management.

Most investigations conducted on the relation among environmental and social costs disclosure and financial performance are uncertain or contradictory, revealing positive or, in some cases, negative outcomes. Thus, this study introduces earning management as an intermediate variable. Stakeholders theory and agency theory emphasized that environmental and social costs disclosure represent a proper examination mechanism to managing the smart behavior, decreasing the information asymmetry among supervisors and investors with conflicting premiums of the two sets and reflecting the actual financial performance. Based on the above description, the present study aims at exploring the effect of environmental and social costs disclosure on financial performance mediated by earnings management in the top 100 Global Energy Corporations.

\section{LITERATURE REVIEW}

\section{Instrumental Stakeholders Theory}

Instrumental Stakeholder Theory is framed using two hypotheses, proposing a positive connection between Corporate Social Performance (CSP) and Corporate Financial Performance (CFP). An instrumental hypothesis is a monetary theory, forecasting an outcome to occur because of the board choices (Jones, 1991). The subsequent hypothesis is an ethical hypothesis whereby managers are obliged to meet partners' needs than to build the company's estimation. This hypothesis is wider than that of shareholders which claimed that managers should expand investors' estimation (Dibia \& Onwuchekwa, 2015; Watts \& Zimmerman 1978). The instrumental shareholders' hypothesis proposes CSR, which builds stakeholders' fulfillment and, ultimately, financial performance. Defenders of this hypothesis opined that the expansion in CSR and extends in ten years suggests managers locate a financial profit by CSR programs. They furthermore expressed that several investigations reveal a positive relationship between a financial profit and CSR (Orlitzky, Schmidt \& Rynes, 2003; Van Beurden \& Gossling, 2008).

\section{Agency Theory}

In agency theory, agency relationship is an arrangement in which "an individual (the owner of economic resources) or more individuals run another person's (agent) (the one uses and controls these 
resources) work to perform or carry out some services on their behalf, including decision-making authority to the manager (agent)" (Jensen and Meckling, 1976). The essence of this theory is to determine the conflict about the detachment of proprietorship and the board control of corporate assets (Fama and Jensen, 1983). Managers typically have sufficient details than principles. This information asymmetry unfavourably influences the essential's capacity to observe whether their advantage is in effect appropriately served by the agents. In the agency hypothesis, managers are keen on transient business execution, so they hope to accomplish a positive offer value impact.

Moreover, regarding CED, an acceptable corporate reputation and improved associations with various partners can be changed over to access financing. It is argued that constructing a friendly reputation is vital to dealing with investors' impressions. Interest in a proper undertaking reputation may maximize shareholder's wealth. This will further encourage holding unrivalled benefits in capital markets (Salama, 2005). CSR exercises give an increasingly precise risk evaluation for speculators, thus offering access to outer financing at the most conceivable reduced expense. To attract potential investors by the expanded straightforwardness of information, the organization probably progresses and is in a fluid situation in stock exchanges. As such, managers engaged with earning management can be relied upon to make increasingly corporate environmental exposures seeking their advantage.

\section{Legitimacy Theory}

This theory states that the company and the encompassing network have close social relations as both are occupied with a "Social Contract". Social contact theory expresses that the organization's essence in a region for political help and ensured by government guidelines just as the parliament represents the community. This creates an indirect social agreement between the organization and the networks where society appoints expenses and advantages for corporate supportability (Lako A., 2011: 6). Social contract was made as the media to set the order of the community social life. Legitimacy theory is an endeavour of the board framework that is situated in favour of community (society), singular governments and local gatherings. For that, as a framework that underlines arrangements to society, the organization's activities ought to be as per the desires for society.

\section{Empirical Review and Hypotheses Development}

Environmental accounting means identifying and revealing explicit environmental costs, for instance, liability expenses or waste transfer costs. Environmental accounting includes any costs and advantages emerging from changes to the organization's properties or methods, such as the change in thinking and environmental effects. A further feature is that environmental accounting data are not necessarily the outcome of accountants, nor need accountants to apply them. Instead, they represent any data with both explicit and understood money related material utilized as a contribution to the company's decision making, product planners, monetary experts, and office administrators like the consumers of environmental accounting information. It also calls attention to basically any kind of information assembled and inspected by firms (Alam, Zhu, Croft, Ho \& Giusarma, 2016).

The empirical study on the relationship between environmental and social costs disclosure and financial performance is not clear yet as some investigations revealed a negative relationship while others showed a positive one. However, other investigations found no relationship at all. From a positive perspective, a proper association with employees, suppliers and clients is vital for the organization's endurance while raising few shareholders with regard to CSR, such as symbolic or kind management skill. In particular, CSR resembles reputation and the organization's reputation. In this manner, when an organization builds its expense or costs by improving CSR disclosure to increase competitive advantages, such CSR practices can enhance or increase organization reputation; therefore, the long sustainability would more improve the financial performance (Oduol, 2009).

The main goal of environmental accounting is providing information about environment-related activities in addition to information generated by conventional accounting. Several and varied definitions of environmental accounting were drawn by scholars. So, it is defined as the field that 


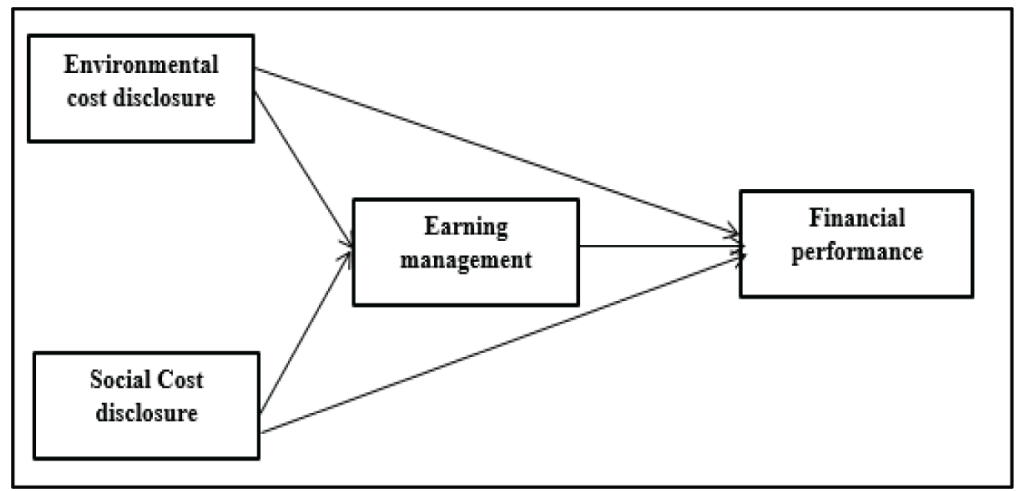

comprises three distinctive contexts: financial accounting, management accounting and national income accounting, representing various national, regional and firm levels, applicable to a product line, a facility, an activity or a system (Bennett \& James, 1997; Gray \& Bebbington, 2000). In the field of green accounting, researchers focus on the impacts of environmental accounting on firms at level or subsets of environmental accounting areas. The environmental and financial accounting focuses on disclosing environment-related information, such as costs associated with environmental liabilities and other environment-related costs. Moreover, Mohammad, Prihat, Sutrisno and Rosidi (2013) explored the impact of environmental information disclosure, using data revelation as mediation on organization esteem. They selected (59) organizations from Indonesia. They concluded that environmental accounting usage did not influence the company value through environmental information disclosure.

Likewise, Nor, Bahari, Adnan, Kamal, \& Ali (2016) studied the impacts of environmental information on financial performance in Malaysia, using top (100) organizations listed in market for the year 2011. Their results showed the presence of environmental disclosure practices in Malaysia. Moreover, Cortez and Cudia (2011) contextually analysed Japanese gadgets organizations to determine the effect of environmental developments on their financial performance exhibition. They associated corporate social performance with benefit in electronic test organizations listed in the Tokyo Stock Exchange. Their findings focused on efforts of risk minimization in electronics firms despite decline in profitability.

Moreover, Uwuigbe \& Jimoh (2012) examined corporate environmental disclosure, focusing much on cement manufacturing firms without analysing the cost components of the firms. It is found that in addition to other things, the degree of environmental disclosure practices is still very low. Moreover, Adediran and Alade (2013) explored the influence of environmental and social accounting on performance in (14) randomly selected Nigerian organizations. The data gathered from the annual report were analysed by employing Regression Analysis. It showed a negative connection between environmental accounting and profit for capital utilized and gaining per share. Besides, Odatayo, Adeyemi, and Sajuyigbe (2014) completed a comparative report on the effect of CSR on the banks' profits in Nigeria. The experimental examination tested six Nigerian banks from 2003-2012, using the annual report and simple regression analysis. It is found that there is a considerable connection between CSR and profits in Nigerian banks. Likewise, Palmer (2012) and Alden, Al, Sukoharsono and Andayani (2019) investigated CSR and financial performance. They argued that firm's social responsibility and company's financial performance have an essentially positive relationship between the two and that the firm's social performance enhances the increase in gross margin.

Moreover, Chih, Shen and Kang (2008) utilized an alternative variable to distinguish earning management. CSR is used and measured by scores from SiRi ProTM information in eight fields of 
research, for example, business exercises and CSR activities. It is found that CFP is a significant control variable when inspecting the relations among CSR and EM using varied perspectives of Chih et al. (2008) and Alden et al. (2019) who argued that when the managers demonstrate their very own support of overseeing income, there are more intentions to take part in several CSR exercises. Moreover, they proposed that CSR is seen as a secondary tool to accumulate support from other groups of stakeholders, whose benefits are damaged by earning management practices. Thus, corporate governance $(\mathrm{CG})$ working as a controlled system is a protection mechanism to reinforce and improve organizational legitimacy. In this way, organizations are inspired to focus on CSR, for example, volunteering in the community or socially and environmentally conscious investments, and social and environmental disclosure responses affecting corporate financial performance. Hence, more obligations will be performed if firms implement the CSR practices as an outcome of earnings manipulation, the positive effect of CSR on CFP is negatively mitigated. Based on this discussion, the hypotheses are formed as shown in Table 1.

Table 1. Hypotheses Development

\begin{tabular}{|l|l|}
\hline H1 & The Environmental cost has a significant effect on the reduction the earning management \\
\hline H2 & $\begin{array}{l}\text { The environmental cost has a significant effect on the increase in financial performance } \\
\text { The environmental cost has a significant effect on the increase in financial performance mediated } \\
\text { by earnings management }\end{array}$ \\
\hline H4 & The social cost has a significant effect on the reduction the earning management \\
\hline H5 & The social cost has a significant effect on the increase in financial performance \\
\hline H6 & $\begin{array}{l}\text { The social cost has a significant effect on the increase in financial performance mediated by } \\
\text { earnings management }\end{array}$ \\
\hline H7 & Earnings management has a significant effect on the reduction in financial performance \\
\hline
\end{tabular}

\section{RESEARCH METHODOLOGY}

The present investigation employed a quantitative method and Smart PLS to examine the data. The largest 250 Global Energy Corporations represented the research community, using annual survey by S\&P Global Platts and the data extracted from Platts as main source (website https://top250.platts. com) for years 2016, 2017 and 2018. Furthermore, secondary data used in this research included the annual corporation reports, financial corporation reports and CSR corporation reports. In this study, the corporations which own assets more than 5 billion in USD currency were selected. The primary and market data were extracted from a database, which was compiled and maintained by S\&P Global Market Intelligence. The final sample was one hundred corporations. This study consisted of four variables, as clarified in Table (2).

Earnings Management (EM) is measured by Shah, Butt and Hasan (2009) using two methodologies. Formerly, most analysts preferred cash flow method. For example, Collins and Hriber (2002) supported the utilization of cash flow-based methodology for the computation of all-out collections. Keeping in mind the equivalent, cash flow-based methodology had been utilized for figuring absolute gatherings according to the following condition:

$\mathrm{TAt}=\mathrm{Nit}-\mathrm{CFOt}$ 
Table 2. Operational Variables

\begin{tabular}{|l|l|l|l|}
\hline \multicolumn{1}{|c|}{ Variables } & \multicolumn{1}{|c|}{ Indicators } & Data source & \multicolumn{1}{c|}{ Operational Definition } \\
\hline $\begin{array}{l}\text { Environmental Cost } \\
\text { Disclosure (ECD) }\end{array}$ & $\begin{array}{l}\text { GRI guideline } \\
\text { environment }\end{array}$ & SCR report & $\begin{array}{l}\text { Environmental costs are any costs incurred } \\
\text { by firms so as to save the environment, solve } \\
\text { its problems and decrease its destruction } \\
\text { (Gholami, Neia, Gohari \& Rad, 2013; Tanc \& } \\
\text { Gokoglan, 2015). }\end{array}$ \\
\hline $\begin{array}{l}\text { Social Cost Disclosure } \\
\text { (SCD) }\end{array}$ & $\begin{array}{l}\text { GRI guideline } \\
\text { Social }\end{array}$ & SCR report & $\begin{array}{l}\text { Social cost refers to any cost spent by firm for } \\
\text { becoming more civic-minded, behave in a more } \\
\text { socially responsible way and avoid financial } \\
\text { scandals }\end{array}$ \\
\hline $\begin{array}{l}\text { Financial Performance } \\
\text { (FP) }\end{array}$ & $\begin{array}{l}\text { Return on Capital } \\
\text { Employed }\end{array}$ & Financial report & $\begin{array}{l}\text { Financial performance refers to performing } \\
\text { financial action. In a more comprehensive } \\
\text { sense, financial performance goes beyond to } \\
\text { how much financial base being or has been } \\
\text { practiced (Hafizah, 2015; Sunny Biobele \& } \\
\text { Ikechukwu Paul, 2012) }\end{array}$ \\
\hline $\begin{array}{l}\text { Earnings Management } \\
\text { (EM) }\end{array}$ & discretionary & Financial report & $\begin{array}{l}\text { Earnings management is the application of } \\
\text { changing the firm's earnings so that financial } \\
\text { statement looks better than their original status }\end{array}$ \\
\hline
\end{tabular}

where (Tat) is the total increase in $t$ year, $(\mathrm{N})$ is the net earning in $\mathrm{t}$ year and (CFOt) is the cash flows from operating activities in $\mathrm{t}$ year.

In the past measurements, there were two sorts of increases: discretionary and non-discretionary accruals. Nevertheless, managers were engaged in providing profit for the management by playing with optional collections. Accordingly, different models were applied for estimating optional increases including DeAngelo Model (1986), Healy Model (1985), Jones Model (1991) and Modified Jones Model (1995). Hence, the up to date and broadly utilized model is Modified Cross-Sectional Jones Model (1995), which was employed in this study. Similarly, optional accumulations were determined by subtracting non-discretionary accruals from complete collections, whereby non-discretionary accruals are inferred as follows:

$\mathrm{NDA}_{\mathrm{t}}=\alpha 1\left(\frac{1}{A t-1}\right)+\alpha 2\left(\frac{\Delta R E V t-\Delta R E C t}{A t-1}\right)+\alpha 3\left(\frac{\Delta P P E t}{A t-1}\right)+\varepsilon$

where $(\triangle \mathrm{REV} t)$ refers to the earnings in year $\mathrm{t}$ minus earnings in year, i.e., $\mathrm{t}-1 ;(\Delta \mathrm{RECt})$ is the net receivables in year $\mathrm{t}$ minus net receivable in year i.e., $\mathrm{t}-1$; $(\Delta \mathrm{PPEt})$ denotes the gross property plant and equipment at the end of year t; (At-1) is the total assets at the end of year $t-1 ;(\alpha 1, \alpha 2, \alpha 3)$ are firm-specific parameters and $(\varepsilon)$ is termed to be residual.

Total accruals extracted from cash flow were relapsed concerning a contrast between an adjustment in income and a change in net receivable (in the present year) and change in property, plant, and equipment (current year), for ascertaining the occurrence of $\alpha 1, \alpha 2, \alpha 3$ in the condition. Accordingly, coefficient regards were balanced in the condition mentioned to infer non-discretionary accumulations. In conclusion, the optional accumulations were inferred by subtracting non-discretionary from total accruals, as demonstrated below:
$\mathrm{DA}=\mathrm{TA}-\mathrm{NDA}$
$\mathrm{DA}=$ Discretionary component of accruals
$\mathrm{TA}=$ Total accruals 


\begin{tabular}{|l|l|l|l|l|}
\hline & Cronbach's Alpha & \multicolumn{1}{c|}{$\begin{array}{c}\text { Composite } \\
\text { Reliability }\end{array}$} & Communality & (AVE) \\
\hline CP & 1 & 1 & 1 & 1 \\
\hline ECD & 1 & 1 & 1 & 1 \\
\hline EM & 1 & 1 & 1 & 1 \\
\hline SCD & 1 & 1 & 1 & 1 \\
\hline
\end{tabular}

NDA $=$ non-discretionary accruals

The disclosure of environmental cost includes disclosure for the management approach which comprises environmental aspects (for example, materials, vitality, water, biodiversity, outflows, effluents and waste), items and administrations, consistence, transport, and in general, objectives applicable to environment viewpoints, strategy, hierarchical duty, checking and development and extra relevant data (GRI, Sustainability Reporting Guidelines).

The social cost disclosure dimension of reasonability concerns the impacts on affiliation it has on the social systems within which it works. The disclosure of social cost would be categorized into four perspectives: labor practices and tolerable work, human rights, society and product duty. The information to be unveiled would be the financial performance and environmental performance including the management approach, objectives, strategy, authoritative duty, preparing and awareness, observing and follows up, and extra logical data. Each information would be accounted depending on the relationship of social viewpoints (GRI, Sustainability Reporting Guidelines). GRI rule scoring would be utilized in measurement if the organization revealed the GRI based rule; giving (0.5) social materials, (1.0) condition material and (0.0) for no disclosure.

Financial performance is the extent of how far good a firm can run the assets from its fundamental mechanism for achieving sustainable business and making revenues. The aspects of financial performance to be measured are categorized in indicator of Return on Asset (ROA), which was used as an intermediate for financial performance in this examination. Indeed, many organizations globally always work to develop their performance through financial techniques (Al-Naser, 2010).

\section{FINDINGS}

\section{Evaluation Model}

The evaluation model used in this study was based on partial least squares (PLS) to roughly calculate parameters and predict cause and effect relationships by assessing the outer model as well as the inner model.

Assessment of the model was done in three phases for the sake of specificity: convergent validity, testing of discriminant validity, and testing of reliability.

\section{Convergent Validity}

Based on Table 3, it is clear that the estimation of AVE and Communality in each development was bigger than (0.5). Thus, the external loading test, shown in table 4, was over (5.2) and index esteem was bigger than (0.7). Therefore, in light of the management results, it may be well presumed that the convergent legitimacy was met. To test discriminant validity: Cross-Loading was examined on the off chance that the estimation of one specific variable or construct was more than (0.7). Given the Cross-Loading (shown in table 5), it is inferred that if the discriminant validity met for each marker 
Table 4. Outer Loading

\begin{tabular}{|l|l|l|l|l|}
\hline & \multicolumn{1}{|c|}{ CP } & \multicolumn{1}{c|}{ ECD } & \multicolumn{1}{c|}{ EM } & SCD \\
\hline CP & 1.0000 & & & \\
\hline ECD & & 1.0000 & & \\
\hline EM & & & 1.0000 & \\
\hline SCD & & & & 1.0000 \\
\hline
\end{tabular}

Table 5. Cross Loading

\begin{tabular}{|l|l|l|l|l|}
\hline & \multicolumn{1}{|c|}{ CP } & \multicolumn{1}{c|}{ ECD } & \multicolumn{1}{c|}{ EM } & \multicolumn{1}{c|}{ SCD } \\
\hline CP & 1.0000 & 0.3948 & -0.7422 & 0.5672 \\
\hline ECD & 0.3948 & 1.0000 & -0.5573 & 0.2523 \\
\hline EM & -0.7422 & -0.5573 & 1.0000 & -0.6078 \\
\hline SCD & 0.5672 & 0.2523 & -0.6078 & 1.0000 \\
\hline
\end{tabular}

in every factor was more than (0.7) regardless of indistinguishable conditions from the past loading factor evaluation, there would be an estimation less than (0.7). Yet, this is simultaneously considered substantial because the variable has esteem bigger than (0.5). However, reliability test was done using two strategies: Cronbach's Alpha, which was larger than (0.6) and composite reliability esteem, which was supposed to be higher than (0.7). As indicated by calculation in table 3 , all factors had the estimation of Cronbach's Alpha, which was higher than (0.6). The composite reliability esteems were more than (0.7). Therefore, the information and consequences of estimations were safe and reliable.

In Table $6, \mathrm{R}^{2}$ value for earnings management was 0.5437 , indicating the data research variability that possibly revealed the model structure as $54 \%$; whereas, another $45 \%$ would be affected by another variable undescribed in this research. While $\mathrm{R}^{2}$ for financial performance was 0.5722 , denoting another independent variable that would influence $57 \%$ of results variable. According to this outcome, the structural model of this investigation had a considerable adequacy.

Figure 2. Equation Model

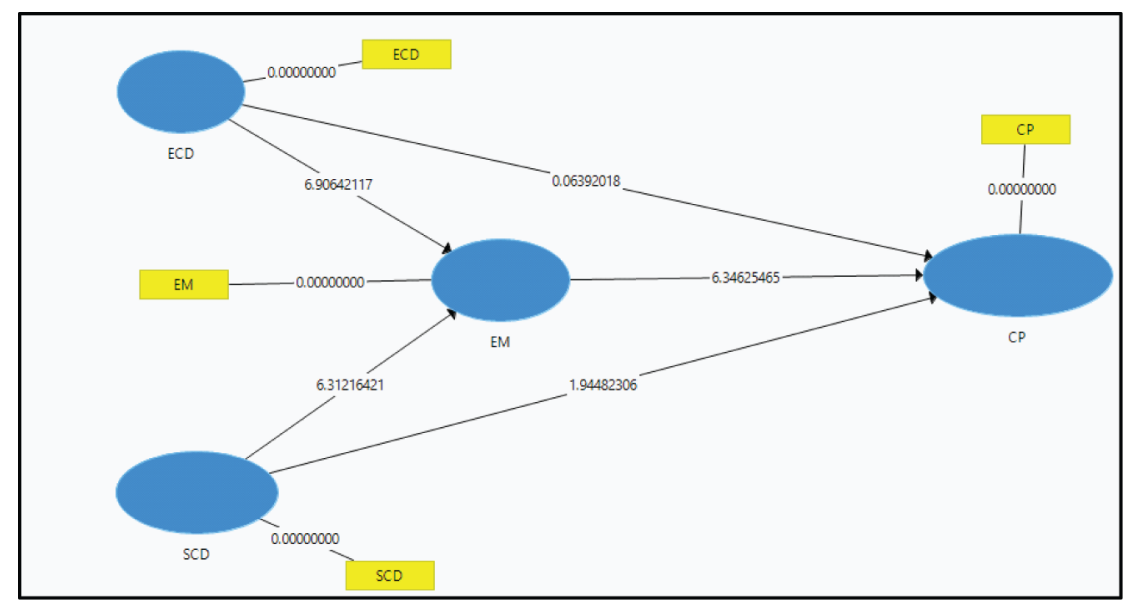




\begin{tabular}{|l|l|}
\hline \multicolumn{1}{|c|}{ Variable } & \multicolumn{1}{c|}{ R Square } \\
\hline EM & 0.5437 \\
\hline CP & 0.5722 \\
\hline
\end{tabular}

\section{Hypotheses Testing}

There were direct and indirect effects, as clarified in table 7. In hypothesis testing, when the coefficient path resulted from T-statistics was bigger than 1.96 or $\mathrm{p}$-value $<5 \%$ (0.05), the alternative hypothesis could be expressed as supported. Moreover, if the estimation of T-statistics was less than 1.96 or p-value $>5 \%$ (0.05), at that point, the alternative hypothesis was not supported.

Based on research model, the equation is:

$\mathrm{EM}=\mathrm{ECD}+\mathrm{SCD}+\varepsilon$

$\mathrm{CP}=\mathrm{ECD}+\mathrm{SCD}+\mathrm{EM}+\varepsilon$

$\mathrm{X} 1=$ Environmental Cost Disclosure $(\mathrm{ECD})$

$\mathrm{X} 2=$ Social Cost Disclosure (SCD)

$\mathrm{Y} 1=$ Earning Management (EM)

Y2= Financial Performance $(F P)$

Hypotheses no (1): The outcome of hypotheses testing on the environmental costs had a significant effect on the reduction of the earning management and T-test was 7.2001; while T-table was 1,96, because T-test $>$ T-table that is $7.2001>1.96$ or p-value $(0.000)<\alpha=0.05$. This influenced X1 environmental cost on earnings management. It can be concluded that Hypothesis 1 is accepted.

Hypotheses no (2): The outcome revealed the significant effect of environmental cost on the enhancement of the financial performance. T-test was 4.8455; while T-table was 1, 96 because T-test $>$ T-table that is $4.8455>1.96$ or p-value $(0.000)<\alpha=0.05$. This indicates that X2 environmental cost on financial performance results was significant. So, Hypothesis 2 is accepted.

Hypotheses no (3): The results of environmental cost effect on the increase of the financial performance mediated by earnings management indicated that T-test was 4.8455; while T-table was 1,96 because T-test $>$ T-table that is $4.8455>1.96$ or $\mathrm{p}$-value $(0.000)<\alpha=0.05$. Thus, Hypothesis 3 is accepted.

Table 7. T-Test direct effect

\begin{tabular}{|c|c|c|c|c|c|}
\hline Construct & $\begin{array}{c}\text { Original } \\
\text { Sample }\end{array}$ & Sample Mean & Standard Deviation & T-Statistics & P Values \\
\hline ECD -> EM & -0.4314 & -0.4311 & 0.0599 & 7.2001 & 0.0000 \\
\hline ECD -> CP & 0.2731 & 0.2740 & 0.0564 & 4.8455 & 0.0000 \\
\hline ECD -> EM - > CP & 0.2731 & 0.2740 & 0.0564 & 4.8455 & 0.0000 \\
\hline SCD -> EM & -0.4990 & -0.5028 & 0.0760 & 6.5685 & 0.0000 \\
\hline SCD -> CP & 0.4994 & 0.5009 & 0.0726 & 6.8806 & 0.0000 \\
\hline SCD -> EM -> CP & 0.3159 & 0.3195 & 0.0695 & 4.5441 & 0.0000 \\
\hline EM -> CP & -0.6331 & -0.6369 & 0.1043 & 6.0702 & 0.0000 \\
\hline
\end{tabular}


Hypotheses no (4): The results of social cost on the reduction of earning management revealed that T-test was 6.5685; while T-table was 1,96 as T-test $>$ T-table that is $6.5685>1.96$ or p-value $(0.000)<\alpha=0.05$. Hence, Hypothesis 4 is accepted.

Hypotheses no (5): The outcome of social cost on the financial performance implied that T-test was 6.8806; while T-table was 1.96 since T-test $>$ T-table that is $6.8806>1.96$ or p-value $(0.000)$ $<\alpha=0.05$. Therefore, Hypothesis 5 is accepted.

Hypotheses no (6): The outcome of social cost on the financial performance mediated by earnings management showed that T-test was 4.5441; while T-table was 1.96 as T-test $>$ T-table that is $4.5441>1.96$ or p-value $(0.000)<\alpha=0.05$. Thus, the influence of X1 environmental cost on earnings management results was significant. Therefore, Hypothesis 6 is accepted.

Hypotheses no (7): The results of earning management on the reduction of financial performance revealed that T-test was 6.0702; while T-table was 1.96 as T-test $>$ T-table that is $6.0702>1.96$ or p-value $(0.000)<\alpha=0.05$. Therefore, Hypothesis 7 is accepted.

\section{Discussion}

The findings of this study showed a relationship between environmental and social costs disclosure and financial performance mediated by earnings management. Based on these results, the direct effect was measured using validity test depending on relevant previous results. Hence, the environmental cost has a remarkable impact on the reduction of the earning management. This result is consistent with that found by Prioret, Surroca and Tribo (2008) who revealed that CSR practices are considered a powerful device to accumulate supported by different partners whose interests are damaged by earnings management practices. Moreover, Corporate Governance as a checking framework is a key system to strengthen or fix organizational authenticity. In this manner, organizations are persuaded to focus on CSR practice, for example, voluntary, corporate, social and environmental disclosure responses, which will impact their financial performance. Nevertheless, they remark that if an organization takes part in CSR exercises as a result of income control, the favourable effect of CSR on CFP will be adversely relieved. Thus, this result agrees with agency theory.

The environmental cost influences the enhancement of financial performance, which is consistent with the shareholder's theory. There is a positive relationship between Corporate Social Performance (CSP) and CFP. This result differs from that found by Mohammad et al. (2013) and Cortez and Cudia (2011), which showed that firms' expenses on environmental and social issues are not proportionate to their financial performance and that CSR is a matter of concern to the government. Thus, the environmental cost has a considerable impact on enhancing corporate performance mediated by earning management.

This relationship between social cost disclosure and financial performance can be explained by companies trying to reduce the implicit costs to act socially responsible. That would increase the explicit cost and, in turn, lead to a competitive disadvantage (decline in profits). Thus, social cost disclosure and CSR improve relations with stakeholders. This relationship increases competitive advantage and improves financial performance. Overall, environmental and social cost disclosures are activities that give an increasingly precise risk assessment for stakeholders, and, therefore, will offer access to outside financing at the most conceivable reduced expense. With respect to bringing more potential stakeholders through the expanded straightforwardness of information, the organization is probably going to be in a progressively hard and flexible situation in stock exchanges. Finally, managers engaged in profit controls are required to make increasingly corporate environmental disclosures, seeking their very own advantage. 


\section{CONCLUSION}

From an accounting perspective, this study aimed at examining the effect of environmental and social costs disclosure on financial performance mediated by earnings management based on the literature available and applicable theories including instrumental stakeholders, agency and legitimacy. The study revealed the impact of environmental and social costs disclosure on financial performance mediated by earning management. Consequently, the environmental and social disclosure has a considerable impact on increasing corporate performance, which is consistent with theories of instrumental stakeholders, agency and legitimacy. This means that more cost on environmental and social information disclosure can create a room for an organization to enhance its reputation. Hence, most organizations announce environmental data to clarify their activities and needs. The environmental exposure for the management approach comprises of environmental factors like materials, water, energy, biodiversity, outflows, effluents, waste, items, services, consistence and transport. Moreover, the cultural concern will, in general, be recognized as a considerable corporate responsibility to communicate among organizations and society with respect to social obligation and sustainability. The social disclosure cost would be divided into four viewpoints: labor practice and conventional work, human rights, society and product responsibility. Accordingly, the corporate social and environmental revelation may be treated as a genuine and social commitment made by the association. However, because of inadequate reviewing regarding the genuine economy, managers have motivating forces to take optional activities over revealed salary to maximize their advantage. Moreover, the earnings management will accumulate when managers mislead some stakeholders about the underlying economic performance of the corporation.

\section{ACKNOWLEDGMENT}

The authors are very grateful to the University of Mosul, College of Administration and Economics for their provided facilities, which helped to improve the quality of this work. 


\section{REFERENCES}

Adediran, S., \& Alade, S. (2013). The impact of environmental accounting on corporate performance in Nigeria. European Journal of Business and Management, 5(23), 141-152.

Ageda, E. O. (2015). The effect of board diversity on the financial performance of the trading and manufacturing companies listed in the Nairobi Securities Exchange (Master thesis). University of Nairobi.

Al-Naser, K. (2010). The Completeness between the Financial and Non-financial Measures for Achieve Monitoring on the Operating Process. Tanmiat al-Rafidain Journal, 32(99), 1-33.

Alam, S., Zhu, H., Croft, R. A. C., Ho, S., \& Giusarma, E. (2016). The Effects of Environmental Accounting On A Developing Nation: Nigerian Experience. European Journal of Accounting. Auditing and Finance Research, 11(September), 1-11.

Alden, H., Al, R., Sukoharsono, E. G., \& Andayani, W. (2019). The impact of Board characteristics on earning management in the international Oil and Gas Corporations. Academy of Accounting and Financial Studies Journal, 23(1), 1-26.

Ali, M., Ahmed, K., \& Henry, D. (2004). Disclosure compliance with national accounting standards by listed companies in South Asia. Accounting and Business Research, 34(3), 183-199. doi:10.1080/00014788.2004.9 729963

Barnett, M. L. (2007). Stakeholder influence capacity and the variability of financial returns to corporate social Responsibility. Academy of Management Review, 32(3), 794-816. doi:10.5465/amr.2007.25275520

Bennett, M., \& James, P. (1997). Environmental management accounting: current practice and future trends. Greener Management International, 32-52.

Biobele \& Ikechukwu. (2012). The Impact of Environmental accounting and reporting on sustainable development in Nigeria. Research Journal of Finance and Accounting, 3(7), 36 - 43.

Bussy, N. M., \& Suprawan, L. (2012). The impact of employee orientation on corporate financial performance. Public Relations Review, 38(2), 280-287. doi:10.1016/j.pubrev.2011.11.006

Cavaco, S., \& Crifo, P. (2014). CSR and financial performance: Complementarity between environmental, social and business behaviours. Applied Economics, 46(27), 3323-3338. doi:10.1080/00036846.2014.927572

Chih, H. L., Shen, C. H., \& Kang, F. C. (2008). Corporate social responsibility, investor protection, and earnings management: Some international evidence. Journal of Business Ethics, 79(1), 179-19. doi:10.1007/s10551007-9383-7

Collins, D., \& Hribar, P. (2002). Errors in estimating accruals: Implications for empirical research. Journal of Accounting Research, 40(1), 105-135. doi:10.1111/1475-679X.00041

Cortez, M. A. A., \& Cudia, C. P. (2011). Sustainability and firm performance: a case study of Japanese electronics companies. Ritsumeikan International Affairs, 10, 321-339.

DeAngelo, L. E. (1988). Managerial competition, information costs, and corporate governance: The use of accounting performance measures in proxy contests. Journal of Accounting and Economics, 10(1), 3-36. doi:10.1016/0165-4101(88)90021-3

Dibia, N. O., \& Onwuchekwa, J. C. (2015). Determinants of environmental disclosures in Nigeria: A case study of oil and gas companies. International Journal of Finance and Accounting, 4(3), 145-152.

El Raey, M. (2006). Air Quality and Atmospheric Pollution in the Arab Region. United Nations National Environment Programme, Regional Office for West Asia.

Eljayash, K. M., James, K., \& Kong, E. (2012). The quantity and quality of environmental disclosure in annual reports of national oil and gas companies in Middle East and North Africa. International Journal of Economics and Finance, 4(10), 201-217. doi:10.5539/ijef.v4n10p201

Epstein, M. J., \& Buhovac, A. R. (2014). A new day for sustainability. Strategic Finance, 96(1), 25. 
Fama, E. F., \& Jensen, M. C. (1983). Separation of ownership and control. The Journal of Law \& Economics, 26(2), 301-325. doi:10.1086/467037

Gholami, S., Neia, A. T., Gohari, B., \& Rad, B. K. (2013). Environmental Accounting (From concepts and Practice). Journal of Basic and Applied Scientific Research, 3(1), 439-443.

Gholami, S., Neia, A. T., Gohari, B., \& Rad, B. K. (2013). Environmental Accounting (From Concept to Practice). Journal of Basic and Applied Scientific Research, 3, 439-443.

Gray, R., \& Bebbington, J. (2000). Environmental accounting, managerialism and sustainability: Is the planet safe in the hands of business and accounting? Advances in Environmental Accounting \& Management, 1. Management, 1, 1-44.

Gray, R., Bebbington, J., \& Walters, D. (1993). Accounting for the environment. Paul Chapman Publishing.

Hafizah, A. M. (2015). Sustainability reporting, dedicated and transient institutional ownership, and financial performance (Doctoral dissertation). Universiti Utara Malaysia.

Healy, P. M., \& Wahlen, J. M. (1999). A Review of the earnings management literature and its implications for standard setting. Accounting Horizons, 13(4), 365-383. doi:10.2308/acch.1999.13.4.365

Jensen, M. C., \& Meckling, W. H. (1979). Theory of the firm: Managerial behavior, agency costs, and ownership structure. In Economics social institutions (pp. 163-231). Springer. doi:10.1007/978-94-009-9257-3_8

Jones, J. (1991). Earnings management during import relief investigations. Journal of Accounting Research, 29(2), 193-228. doi:10.2307/2491047

Lako, A. (2011). Deconstruction CSR and Reform Paradigm Business and Accounting. Erlangga.

Mohammad, S. T., \& Assih, R. (2013). Effect of Environmental Accounting Implementation and Environmental Performance and Environmental Information Disclosure as Mediation on Company Value. International Journal of Business and Management Invention, 2(10), 55-67.

Nor, N. M., Bahari, N. A. S., Adnan, N. A., Kamal, S. M. Q. A. S., \& Ali, I. M. (2016). The effects of environmental disclosure on financial performance in Malaysia. Procedia Economics and Finance, 35, 117-126. doi:10.1016/ S2212-5671(16)00016-2

Odetayo, T. A., Adeyemi, A. Z., \& Sajuyigbe, A. S. (2014). Impact of Corporate social responsibility on profitability of Nigerian banks. International Journal of Academic Research in Business and Social Sciences, $4(8), 252-263$.

Oduol, F. O. (2009). A survey of the social accounting and reporting practices adopted by the mobile service providers in Kenya (Unpublished MBA project). School of Business, University of Nairobi.

Orlitzky, M., Schmidt, F. L., \& Rynes, S. L. (2003). Corporate social and financial performance: A meta-analysis. Organization Studies, 24(3), 403-441. doi:10.1177/0170840603024003910

Palmer, I., \& Dunford, R. (2002). Managing discursive tension: The co-existence of individualist and collaborative discourses in flight center. Journal of Management Studies, 39(8), 1045-1069. doi:10.1111/1467-6486.00323

Porter, M. (1991). America's green strategy. Reader in Business and the Environment, 33.

Porter, M. E., \& Van der Linde, C. (1995). Toward a new conception of the environment-competitiveness relationship. The Journal of Economic Perspectives, 9(4), 97-118. doi:10.1257/jep.9.4.97

Prior, D., Surroca, J., \& Tribo, J. (2008). Are socially responsible managers really ethical? Exploring the relationship between earnings management and corporate social responsibility, corporate governance. International Review (Steubenville, Ohio), 16(3), 160-177.

Salama, A. (2005). A note on the impact of environmental performance on financial performance. Structural Change and Economic Dynamics, 16(3), 413-421. doi:10.1016/j.strueco.2004.04.005

Shah, S. Z. A., Butt, S. A., \& Hasan, A. (2009). Corporate governance and earnings management an empirical evidence from Pakistani listed companies. European Journal of Scientific Research, 26(4), 624-638. 
Tanc, A., \& Gokoglan, K. (2015). The impact of environmental accounting on strategic management accounting: A research on manufacturing companies. International Journal of Economics and Financial Issues, 5(2), 566-573.

Uwuigbe, U., \& Jimoh, J. (2012). Corporate environmental disclosures in the Nigerian manufacturing industry: A study of selected firms. African Research Review, 6(3), 71-83. doi:10.4314/afrrev.v6i3.5

Van Beurden, P., \& Gössling, T. (2008). The worth of values-a literature review on the relation between corporate social and financial performance. Journal of Business Ethics, 82(2), 407-424. doi:10.1007/s10551-008-9894-X

Watts, R. L., \& Zimmerman, J. L. (1978). Towards a positive theory of the determination of accounting standards. The Accounting Review, 112-134.

Yusoff, H., Lehman, G., \& Nasir, N. M. (2006). Environmental engagements through the lens of disclosure practices. Asian Review of Accounting, 14(1/2), 122-148. doi:10.1108/13217340610729509 